\title{
Gender and Disparaging Humour
}

\author{
Anna Knyazyan \\ Yerevan State University
}

\begin{abstract}
The article covers the problem of deprecating humor in English anecdotes. It deals with the issue of using invective lexical units in comic discourse. Women swear considerably less than men. Aggressive anecdotes frequently disparage women. Generalizations about women and men inevitably involve false assumptions as they refuse to acknowledge the diverse identities, aspirations and personalities of individual women and men. Women are the brunt of more jokes than men. In English anecdotes men's voice dominates. Conceptions of male dominance and patriarchy have also affected the lens through which we view the maternal image in language socialization practices.
\end{abstract}

Key words: gender roles, gender stereotypes, male, female, deprecating and disparaging humor.

\section{Introduction}

Gender differences pervade every aspect of human personality and appearance, and dictate how males and females should act, think and behave. Gender linguistics is concerned with various aspects of the representation of gender in language. Gender differences can be divided into two categories: how the representatives of opposite genders speak or write, and how they are spoken or written about. It was R.T. Lakoff who highlighted this phenomenon and gave room to many debates and research on gender, and especially on language and gender (Lakoff 1975). Gender consists in a pattern of relations that develops over time to define male and female, masculinity and femininity, simultaneously structuring and regulating people's relation to society. It is deeply embedded in every aspect of society. It goes without saying that gender issues are confronted with the problem of gender stereotypes and clichés in society.

Interest in language and gender research has raised lately. Researchers have examined the relationship between language and gender using numerous methodologies. Humour research has also become increasingly prolific. There are many stereotypes postulating gender differences in using and appreciating humour, but there is a conspicuous lack of studies investigating how humour, namely English humour, is used by men and women in everyday communication. 


\section{Deprecating Humour}

Humour can be found in various everyday situations. Humour, broadly defined, is the "quality or ability to perceive, appreciate or express what is funny, amusing, or ludicrous" (Webster's New World 2001:751). Jokes are short narratives or riddles with a long introduction and a brief comic ending which impute a particular ludicrous trait or pattern of behavior. Due to their brief content, jokes are often based on the means of linguistic economy, therefore many of them rely on simplified and established concepts and stereotypes, formulated by one social group concerning some other group. Humor is a social phenomenon that tends to relieve stress on an individual level and collectively constitutes a powerful mechanism for disseminating both abstract and real-life knowledge about the human condition. It is conceived as a mode of discourse and a strategy for social interaction. The purpose of wit, or humor, is to elicit laughter, but until now, the question of how such humor perpetuates power/status inequity has not been studied directly (Wyer \& Collins 1992).

Because of the broad definition of humor, it is important to note that there is a wide variety of categories within the context of humor. Deprecating or disparaging humor, as defined by Webster's New World (2001:751), "is a type of humor that degrades, or expresses disapproval of another individual or group of individuals".

Disparaging humor has negative consequences on both the individual or psychological levels. On the individual level, disparaging humor is thought to create and reinforce negative stereotypes and prejudice toward the targeted group. The initiation of disparaging humor serves a divisive function. It creates and reinforces hostility toward the targeted group.

Stereotypes are emotion-based and they are often used in a negative or prejudicial sense. Gender-based stereotyping differs from many other well-known cases of stereotyping. Attitudes toward the disadvantaged group of women are very often favorable in content and yet prejudicial in their consequences. Sexist humor has been an integral part of many patriarchal cultures for centuries. Sexist humor demeans, insults, stereotypes, victimizes, and/or objectifies a person on the basis of his or her gender. Importantly, women are more frequently the target of aggressive humor and the object of sexual humor than men are. Based on sexist beliefs about the inferiority of women, such humor portrays them through characteristics such as stupidity, illogical thinking, ignorance, or irresponsibility. Sexism can be very damaging because it reinforces the idea that one gender is superior towards the other. Thus, opportunities are unequally distributed leaning in favor of one gender over the other. Sexist humor tends to build on sexual objectification of women. Sexist jokes can come in general or specified forms. General sexist jokes are told about women directly, disparaging them as a unity. For example, Why don't women mind their own business? No business. No mind. Specified sexist jokes mock certain feminine groups, characterizing them by an exaggeration of traditional feminine stereotypes. For example, the dumb blonde is an embellished version of "dumb women" and "sex object" stereotypes, while mother-in- 
law-centered humor employs the stereotype of threatening, castrating, sexless womanhood. General sexist jokes are explicit in their focus on gender. Gender in specified sexist jokes is often implicit - encoded in well-known stereotypes that are not labeled explicitly as relating to gender.

Humour is conveyed in various ways, most notably through speech. People usually have hundreds of daily interactions, in which they use language to express their ideas, thoughts, beliefs, and values, and, moreover, to affect those around them. Ford, Wentzel, and Lorion (2001) found that exposure to disparaging humor will only affect a listener's stereotypes if the target of the humour are the disadvantaged (e.g., women).It was hypothesized that there may be gender differences in speakers' use of deprecating humor. In anecdotes women become targets of deprecatory humor more frequently than men do.

For example:

(1) Mrs. Jones goes to the doctor for a full medical examination.

After an hour or so, the doctor looks at Mrs. Jones and says the following:

"Mrs. Jones, overall you are very healthy for a 45-year old. There is however, only one problem. You are 4 stone overweight and bordering on obese. I would strongly suggest that you diet now to save any complications in later years."

She looks sternly at him and says, "I demand a second opinion."

"OK” he says, "you're fucking ugly as well!"”

(2) A wife asked her husband, "What do you like most in me, my pretty face or my sexy body?"He looked at her from head to toeand replied, "I like your sense of humor!" 2

Both men and women would prefer to listen to females be deprecated than males. This type of humor creates a social status hierarchy, so that the speaker is superior and the subject is inferior within an utterance. Therefore, in order to identify which stereotypes are upheld, it is important to differentiate which gender is making these remarks and to discover what implications they might have on an individual and the society.

Superiority and inferiority are conveyed through the words speakers use in daily interactions. Conversations (telling anecdotes) allow for many instances of humor use, in particular, opportunities for deprecating remarks. People jokingly call others “bastard", “bitch", “stupid”, “loser", "silly" or "foolish", "fool” to assert their place within the social status hierarchy.

For example: 
(3) A guy gets home early from work and hears strange noises coming from the bedroom. He rushes upstairs to find his wife naked on the bed, sweating and panting.

"What's up?" he asks.

"I'm having a heart attack!' cries the woman.

He rushes downstairs to grab the phone, but just as he's dialing, his four-year-old son comes up and says, "Daddy! Daddy! Uncle Ted's hiding in your closet, and he's got no clothes on!"

He slams the phone down and storms upstairs into the bedroom, past his screaming wife. He rips open the closet door. Sure enough, there is his brother, totally naked, cowering on the floor.

"You bastard," says the husband. "My wife is having a heart attack, and you're running around with no clothes on scaring the kids! $!^{3}$

(4) A young woman is alone in a railway carriage when a dishevelledlout walks in, sits opposite her and takes out a packet of peeled prawns to eat. Belching and farting, he eats his way through the packet and then throws the empty carton onto the floor.

At this point the young woman gets up, gathers together all the rubbish and throws it out of the window. She then pulls the communication cord.

"You silly bitch," he chuckles, "that'll cost you a £50 fine."

"Maybe," replies the lady. "But it'll cost you 15 years when they smell your fingers." 4

Goldstein (1976) concludes that people enjoy hearing jokes that reflect what they believe; they do not enjoy hearing jokes that oppose what they believe. This would indicate that the listener, although he or she finds a joke humorous, does not share the same beliefs as the joke implies. For example, there are a lot of jokes about blondes:

(5) A blonde walks into a doctor's office. She gets in the room with the doctor and says, "Doc, I hurt all over." The doctor is really confused. He says, "What do you mean, you hurt all over?" The blonde says, "I'll show you."

She then touches herself on her leg. "OW!!! I hurt there." Then she touches her earlobe. "OW!!!!!! I hurt there too!" Then she touches her hair. "OW!!!!!EVEN MY HAIR HURTS!'"Sothe doctor sits back and thinks on it for 5 min. Then he says, "Tell me, is blonde your natural hair color?" The blonde says "Yes, why?"

The doctor says, "Well, you got a broken finger..." 
(6) A blonde stormed up to the front desk of the library and said, "I have a complaint!"

"Yes, Ma'am?" said the librarian looking up at her.

"I borrowed a book last week and it was horrible!"

Puzzled by her complaint the librarian asked "What was wrong with it?"

"It had way too many characters and there was no plot whatsoever!" said the blonde.

The librarian nodded and said, "Ahhh. So you must be the person who took our phone book. ${ }^{6}$

(7) A blonde calls Delta Airlines and asks, "Can you tell me how long it'll take to fly from San Francisco to New York City?" The agent replies, "Just a minute..." "Thank you," the blonde says, and hangs up. ${ }^{7}$

A "dumb blonde joke" can be found humorous, even if the listener may not actually hold the belief that blonde women are dumb. He or she may have had experience with intelligent blonde women, which reflects their true feelings. When males tell a "dumb blonde joke" to a male audience, the listeners laugh, endorsing the idea that some women can be dumb, or share similar qualities with the "dumb blonde" in the joke. However, when a male tells this joke to a female audience, their laughter may not signify their endorsement of women being dumb blondes, but rather, by laughter they accept and display their place in society as lesser than males, whether in terms of intelligence or power. Disparaging comments disguised as jokes often refer to the feminine nature of the partner, to her intellectual abilities, or to her competency.

Women face economic, spiritual, physical, emotional and social disadvantages in comparison to men almost in all cultures. Although women are generally equals of men, there are still large disparities in theory and practice of this supposed equality.

According to our statistics twice as many jokes about men are positive in tone than jokes about women; three-quarters of all jokes about women are negative. There are whole categories of jokes about women for which there are no male parallels: prostitute jokes, mother-in-law jokes, dumb blonde jokes, woman driver jokes, Jewish mother jokes. The fact that women are judged by a harsh standard of youth and beauty is presented as an opportunity for women to express their individuality through fashion, starvation dieting and cosmetic surgery.

Sex differences are easy to point out, but difficult to explain. While males typically socialize in groups, females are more likely to have closer, one-on-one relationships with other women (Benenson, Maiese, Dolenszky, Dolenszky, Sinclair, \& Simpson 2002). To maintain this closeness, many females will utilize deprecating humor to maintain dyadic female relationships, in which they are apt to put themselves down in order to ease or comfort those around them (Benenson et. al. 2002). 
Freud claims that self-deprecatory humor is aggression toward others turned inward(Freud1905). Anger at this message may be turned inward, particularly if inferiority has been internalized. In this case, the pleasure of the joke can be read as masochistic or, in the case of those who disparage other women, as an indicator of a psychological need to compare favorably with others who are devalued. Those in power within a culture prefer humor that disparages the powerless, whereas those not in power tend to prefer self-deprecatory humor. But Freud also claims that the ability to laugh at oneself represents the "triumph of narcissism and assertion of invulnerability" (Freud 1905:186). In this model, the individual shifts some of the energy from ego to super ego and "stresses moral values at the expense of pragmatic interests, thus lessening the impact of physical adversity". People laugh at "some sudden conception of some eminency in ourselves, by comparison with the infirmity of others, or with our own formerly" (Wilson1979:89).We laugh at ourselves only when we feel that we are actually distanced from that former inferior self.

Walker notes that: "Laughing at one's shortcomings is not only a way of diminishing their importance and potentially overcoming them but is also a technique for cleansing them of pejorative connotations imposed by the dominant culture and, thereby, turning them into strengths" (Walker1988:96). Females tend to put up a defensive wall that calls attention to their lack of social power before any other person can poke fun at them for the same things (Benenson et. al. 2002). Women are more likely to engage in self-disparaging humor - that is, humor at one's own expense. This humor is at the expense of a person or a group with whom the humorist is closely identified, such as a spouse, mother, father, sibling, or one's own ethnic group. Women hold a disadvantageous role in a society that is deficient or subordinate to that of men. This subordination is expressed in language. Although there are interpretations of gendered language that deny an existing deficiency of women in language, the language features strongly suggest power imbalance in the society. However, this power imbalance may more often be based on ideology than on reality, and similarly, on the established language features, because otherwise, the separation of men and women into those two groups just seems too strict and absolute.

\section{Conclusion}

Sexist humor has broader social consequences, or indirect effects on both women and men. Specifically, sexist humor can potentially create a distressing, hostile environment for women. Sexist humor affects the ways that men think about women and perceive discrimination against them. With the growing awareness that sexist humor can function as a potential tool of prejudice and discrimination, there is a clear need for social scientists to continue conducting empirical research in order to illuminate the potentially complex emotional responses that people may have to sexist humor. There is also a clear need for researchers to continue research in an effort to further delineate the broader social consequences of sexist humor, and thus help us 
better understand how sexist humor shapes social interaction. The current study reveals that a high percentage of men make deprecating utterances targeted towards women. Men joke at the cost of others more often than women do. Women joke about themselves and their experiences. For them joking is a means of establishing common ground and intimacy. Women actively encourage the success of the speaker by providing support through laughter. Men do this less frequently, especially when the speaker is a woman. This is because human society holds women in a position of inferiority, one that is easy to target and easy to disparage.

\section{Notes:}

1. Bigfun com. Available at: <http://www.bigfun.be/Jokes/Doctor+s+Diagnose_4.htm> [Accessed August 2015].

2. Unijokes.com. Available at: <http://unijokes.com/joke-8415/> [Accessed August 2015].

3. Ava7.com. Available at: <http://ava7.com/2006/09/blonde-guy.html> [Accessed August 2015].

4. Sharpe, J. (2004) The Adult Joke Book. London: Arcturus Publishing Limited. 59 p.

5. Some Celebrity Jokes. Available at: <http://www.worthwhilesmile.com/jokes/> [Accessed August 2015].

6. Cool Blonde Jokes. Available at: <http://www.coolblondejokes.com/DumbJokes/ BadBook.shtml $>$ [Accessed August 2015].

7. Some Funnies. Available at: <http://www.tellmeastory.freeuk.com/funnies/10 87.Htm $>$ [Accessed August 2015].

\section{References:}

1. Benenson, J.; Maiese, R.; Dolenszky, E.; Dolensky, N.; Sinclair, N.; Simpson, A. (2002) Group Size Regulates Self-Assertive Versus Self-Deprecating Responses to Interpersonal Competition. // Child Development, 73(6), pp. 1818-1829. Available at: $<$ http://www.onlinelibrary.wiley.com/doi/10.1111/1467-8624.00508/pdf.> [Accessed January 2015].

2. Ford, T.; Wentzel, E.; Lorion, J. (2001) Effects of Exposure to Sexist Humor on Perceptions of Normative Tolerance of Sexism. // European Journal of Social Psychology, 31(6), pp. 677-691. New York: Wiley\& Sons, Ltd.

3. Freud, S. (1905) Jokes and Their Relation to the Unconscious. // The Standard Edition of the Complete Psychological Works of Sigmund Freud James. / Ed. and Tr. by Strachey. Vol. 8, pp. 1-237. London: Hogarth Press.

4. Goldstein, J. (1976) Theoretical Notes on Humor. // Journal of Communication, 26(3), pp.104-112. Oxford: Blackwell Publishing Ltd. 
5. Lakoff, R. (1975) Language and Woman's Place. New York: OUP.

6. Sharpe, J. (2004) The Adult Joke Book. London: Arcturus Publishing Limited.

7. Walker, N. (1988) A Very Serious Thing. Women's Humour and American Culture. University of Minnesota Press; Minnesota Archive Editions.

8. Wilson, C. (1979) Jokes: Form, Content, Use and Function. New York: Academic Press.

9. Wyer, R. \& Collins, J. (1992) A Theory of Humor Elicitation. // Psychological Review, 99(4), pp. 663-688 Boston:American Psychological Association Inc..

10. (2001) Webster's New World College Dictionary. Foster City, CA: IDG Books Worldwide, Inc ( $4^{\text {th }}$ ed. $)$.

\section{Qtuantinn l GutưugGinn hnưnnn}

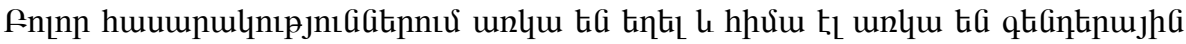

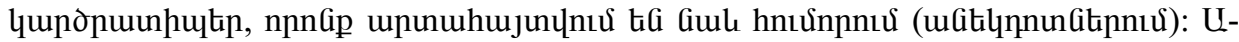

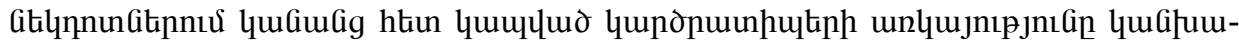

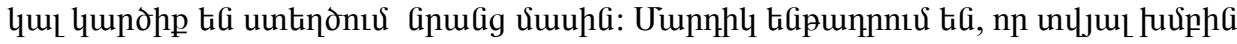

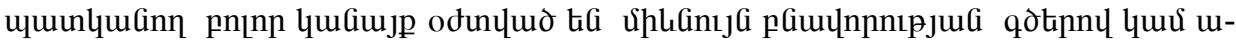

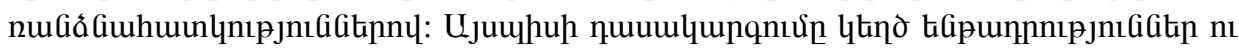

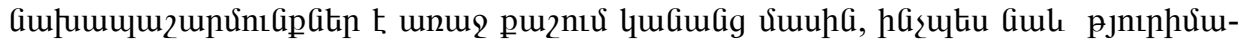

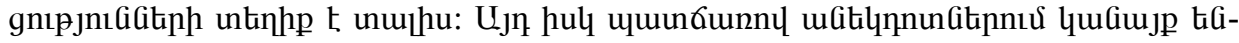

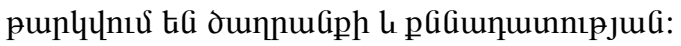

\section{Гендер и уничижительный юмор}

Гендерные оппозиции пронизывают все сферы жизни. Гендерные стереотипы формируют определенную форму поведения, к одним и тем же чертам приписываются разные оценки, в зависимости от того, к какому полу относится данная характеристика. В картине мира, реализуемой в анекдоте, тенденция к андроцентричности является подавляющей. В большинстве случаев анекдоты, касающиеся гендерных аспектов, открыто или завуалированно дискриминируют женщин. 